\title{
Influence of quinacrine and chloroquine on the in vitro 3'-azido-3'-deoxythymidine antiretroviral effect
}

Klintsy J Torres ${ }^{1,2}$, Gustavo Reyes-Terán ${ }^{2}$, Julio Sotelo ${ }^{3}$, Helgi Jung-Cook ${ }^{4,5}$ and Lucinda Aguirre-Cruz ${ }^{1,3^{*}}$

\begin{abstract}
Background: Antimalarials quinacrine $(\mathrm{Qc})$ and chloroquine $(\mathrm{Cq})$ intercalate DNA, potentiate the activity of other drugs and have lysosomotropic, anti-inflammatory and antiviral activities that could increase the effect of the 3'-azido-3'-deoxythymidine (AZT) antiretroviral agent. The aim of the current study was to evaluate if Qc and Cq could improve the in vitro effect of the antiretroviral AZT agent.

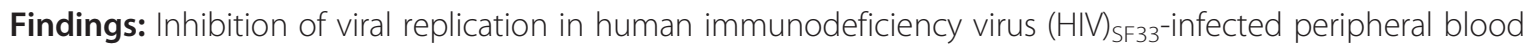
mononuclear cells treated with Qc or Cq, alone or combined with a low dose of AZT was measured. Viral replication increased with Qc and decreased with high doses of Cq. The increase of replication caused by Qc was reversed by AZT. Neither Qc nor Cq significantly changed the antiviral activity of AZT.

Conclusion: $\mathrm{Cq}$ does not potentiate the effect of AZT, but it is effective by itself at high doses. The rise of HIV replication by Qc could be deleterious in HIV endemic regions, where it is used as antimalarial. The mechanisms associated to this phenomenon must be identified.
\end{abstract}

Keywords: Antimalarials, Quinacrine, Chloroquine, AZT, HIV

\section{Findings}

\section{Introduction}

Human immunodeficiency virus (HIV)/acquired immunodeficiency syndrome morbidity and mortality have decreased with the use of antiretroviral therapy (ART). However, therapy adherence is frequently diminished by ART toxicity [1], which might in turn lead to emergence of resistant HIV strains [2].

Chloroquine (Cq) and quinacrine (Qc) have been widely used for decades as antimalarials, both have a well characterized biosafety and pharmacological profile [3]. The accumulation of $\mathrm{Cq}$ in breast milk of HIV infected women [4], and a decreased vertical transmission of HIV induced by this drug have been observed in malaria endemic countries [5]. Cq and Qc also have strong DNA intercalating

* Correspondence: mariluci_aguirre@hotmail.com

'Laboratorio de Neuroimmunoendocrinología, Instituto Nacional de

Neurología y Neurocirugía Manuel Velasco Suárez, Av. Insurgentes Sur 3877,

14269 México D F, México

${ }^{3}$ Laboratorio de Neuroinmunología y

Full list of author information is available at the end of the article properties [6], as well as special tropism for lysosomes [7], and concentrate for long periods in lymphoid tissue $[8,9]$. Due to the afore mentioned pharmacological properties, these drugs could be used as inhibitors of HIV replication $[10,11]$. Both drugs have also been linked to inhibition of: immune activation [12]; intracellular production of interferon [13]; nuclear factor-kappa B activation [14]; calcium signals in T cells [15]; and RNA polymerase activity [16]. Qc intercalation in viral DNA or RNA inhibits DNA mutations [17]. Additionally, Cq potentiates the activity of some antineoplastic drugs [18]. In this study, we evaluated the in vitro effect of Qc and Cq on HIV replication, administered alone or combined with low concentrations of the ART agent, 3'-azido-3'-deoxythymidine (AZT), in order to search for a possible additive effect of the antimalarial drug-AZT combinations.

\section{Methods}

Peripheral blood mononuclear cells (PBMCs) provenient from different human voluntary healthy donors were used instead of $\mathrm{CD}^{+} \mathrm{T}$ cells, for better availability in our laboratory. The protocol was approved by the

\section{Biomed Central}


Research Board of the National Institute of Respiratory Diseases. PBMCs were purified by density gradient centrifugation and cultured at $37^{\circ} \mathrm{C}, 5 \% \mathrm{CO}_{2}$ and $85 \% \mathrm{H}_{2} \mathrm{O}$, in RPMI-1640 medium, supplemented with fetal bovine serum (BioWhittaker, Anaheim CA), antibiotics PenicillinStreptomicyn (BioWhittaker, Anaheim CA), L-Glutamine (BioWhittaker, Anaheim CA) and human IL-2 (20 U/ml, Roche, USA), as previously described [19]. In order to determine the cytotoxicity effect, the viability of uninfected PBMCs, treated at the same drug concentrations, used in the drug assay, was measured using trypan blue exclusion staining $(0.04 \%$, Cambrex, USA). The percentage of viable cells was determined dividing the number of alive cells $x$ $100 /$ total cells. HIV $\mathrm{SF}_{\mathrm{SF} 3}$ virus isolated and donated by Levy et al. [20], was tittered on phytohemagglutinin-stimulated PBMCs for determining the tissue culture infectious dose $50\left(\mathrm{TCID}_{50}\right)$, as described by McDougal [21]. Viral stocks were then stored frozen at $-80^{\circ} \mathrm{C}$ until their use. PMBCs were infected with $\mathrm{HIV}_{\mathrm{SF} 33}\left(500 \mathrm{TCID}_{50} / 1 \times 10^{6}\right.$ cells) by $2 \mathrm{~h}$ at $37^{\circ} \mathrm{C}$, and extensively washed to remove the virus, and cultured during 4 days in the presence of the following treatments: Phosphate Buffered Saline (PBS, $15 \mathrm{mM}$ as control); AZT $\left(0.008 \mu \mathrm{M}, \mathrm{ID}_{50}\right)$; Qc $(0.4-2 \mu \mathrm{M})$; $\mathrm{Cq}$ $(5-20 \mu \mathrm{M})$; or the mixtures Qc $(0.4-2 \mu \mathrm{M})+\mathrm{AZT}$ $(0.008 \mu \mathrm{M})$; Cq $(5-20 \mu \mathrm{M})+\mathrm{AZT}(0.008 \mu \mathrm{M})$. On the fourth day of culture, the viral replication, measured as level of HIV-1 p24 antigen, was tested by EnzymeLinked ImmunoSorbent Assay (ELISA, Beckman Coulter, Fullterton, CA). Absorbance ( $450 \mathrm{~nm}$ ) was measured with the CODA EIA automated Analyzer (Bio-Rad, Hercules, CA) and concentration was calculated with CODA software. All assays were run in triplicate on three different days $(n=9)$, using the same $\operatorname{HIV}_{\mathrm{SF} 33}$ virus stock. The percentage of inhibition of replication was determined by calculating percent reduction HIV p24 antigen in wells containing the drugs and were compared with control (PBS) using the formula: HIV p24 antigen in PBS - HIV p24 antigen drug treatment $\times 100 / \mathrm{HIV}$ p24 antigen in PBS. Statistical analysis included Student's $t$-test to compare cell viability between drug treatment alone or combined and one-way analysis of variance (ANOVA) test followed by the Tukey's post-hoc test to compare inhibition of HIV replication between AZT and Cq or Qc treatments using the GraphPad Prism 6 software. Differences were considered significant when $\mathrm{p}$-value was $<0.05$.

\section{Results}

Table 1 shows the cell viability in cultures treated with AZT, Qc or Cq. It can be seen that the tested dose of AZT $(0.008 \mu \mathrm{M})$ did not reduce cell viability compared to PBS control PBMCs. Both Qc and Cq produced doserelated decreases in cell viability, with significant reductions in percentage occurring at the highest concentrations of Qc $(5 \mu \mathrm{M}, \mathrm{p}=0.038)$ and $\mathrm{Cq}(20 \mu \mathrm{M}, \mathrm{p}=0.004)$, when compared with PBS control. Addition of AZT to Qc or Cq did not cause any further increase in cytotoxicity.

The low dose of AZT used in this report was selected to yield modest inhibition of $\mathrm{HIV}_{\mathrm{SF} 33}$ replication so that effects of coadministration of Qc or Cq could be observed. Treatment with $0.008 \mu \mathrm{M}$ AZT alone significantly inhibited $\mathrm{HIV}_{\mathrm{SF} 33}$ replication by nearly $50 \%(t$-test, $\mathrm{p}=0.0061)$ compared to PBS. Qc (0.4-2 $\mu \mathrm{M})$ administered alone caused increases in HIV replication that appeared to be inversely related to dose of the antimalarial drug (Figure 1A) $(\mathrm{p}=<0.0001)$. This enhancement of viral replication by Qc alone was reversed by co-administration

Table 1 Viability of peripheral blood mononuclear cells treated with PBS, quinacrine, chloroquine or 3'-azido-3'-deoxythymidine ${ }^{a}$

\begin{tabular}{|c|c|c|c|c|c|c|}
\hline \multirow[t]{2}{*}{ Drug } & \multirow[t]{2}{*}{ Dose $(\mu \mathrm{M})$} & \multicolumn{2}{|l|}{ Treatment } & \multicolumn{2}{|c|}{ Treatment combined with AZT $(0.008 \mu \mathrm{M})$} & \multirow[b]{2}{*}{ (p) } \\
\hline & & Cells $^{\mathbf{b}}($ mean \pm SD $)$ & $\%$ of viability & Cells $^{\mathbf{b}}($ mean \pm SD $)$ & $\%$ of viability & \\
\hline PBS (Control) & - & $247 \pm 61$ & $87 \pm 7$ & - & - & - \\
\hline 3'-azido-3'-deoxythymidine, AZT & 0.008 & $238 \pm 70$ & $85 \pm 6$ & - & - & - \\
\hline \multirow[t]{3}{*}{ Quinacrine, Qc } & 0.4 & $213 \pm 66$ & $88 \pm 8$ & $198 \pm 63$ & $90 \pm 5$ & ns \\
\hline & 1 & $186 \pm 96$ & $83 \pm 14$ & $208 \pm 60$ & $86 \pm 7$ & ns \\
\hline & 5 & $139 \pm 69$ & $71 \pm 17^{d}$ & $126 \pm 59$ & $71 \pm 12$ & ns \\
\hline \multirow[t]{3}{*}{ Chloroquine, $\mathrm{Cq}$} & 5 & $216 \pm 64$ & $88 \pm 8$ & $210 \pm 83$ & $89 \pm 5$ & ns \\
\hline & 10 & $184 \pm 67$ & $86 \pm 10$ & $179 \pm 60$ & $84 \pm 7$ & ns \\
\hline & 20 & $106 \pm 36$ & $68 \pm 17^{e}$ & $99 \pm 47$ & $63 \pm 10$ & ns \\
\hline
\end{tabular}

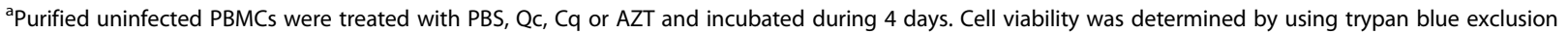
staining. Dead (blue) and alive (unstained) cells were counted. The percentage of viable cells was determined dividing the number of alive cells $\times 100 /$ total cells. ${ }^{b}$ Mean value $(+/-$ standard deviation) of viable cells from three independent assays by triplicate $(n=9)$.

'Student's $t$-test between treatment alone and combined with AZT at the same concentration.

dPost-hoc Tukey's test of concentration compared with control, $p=0.0363$.

'Post-hoc Tukey's test of concentration compared with control, $p=0.0033$.

$\mathrm{ns}=$ not significant. 

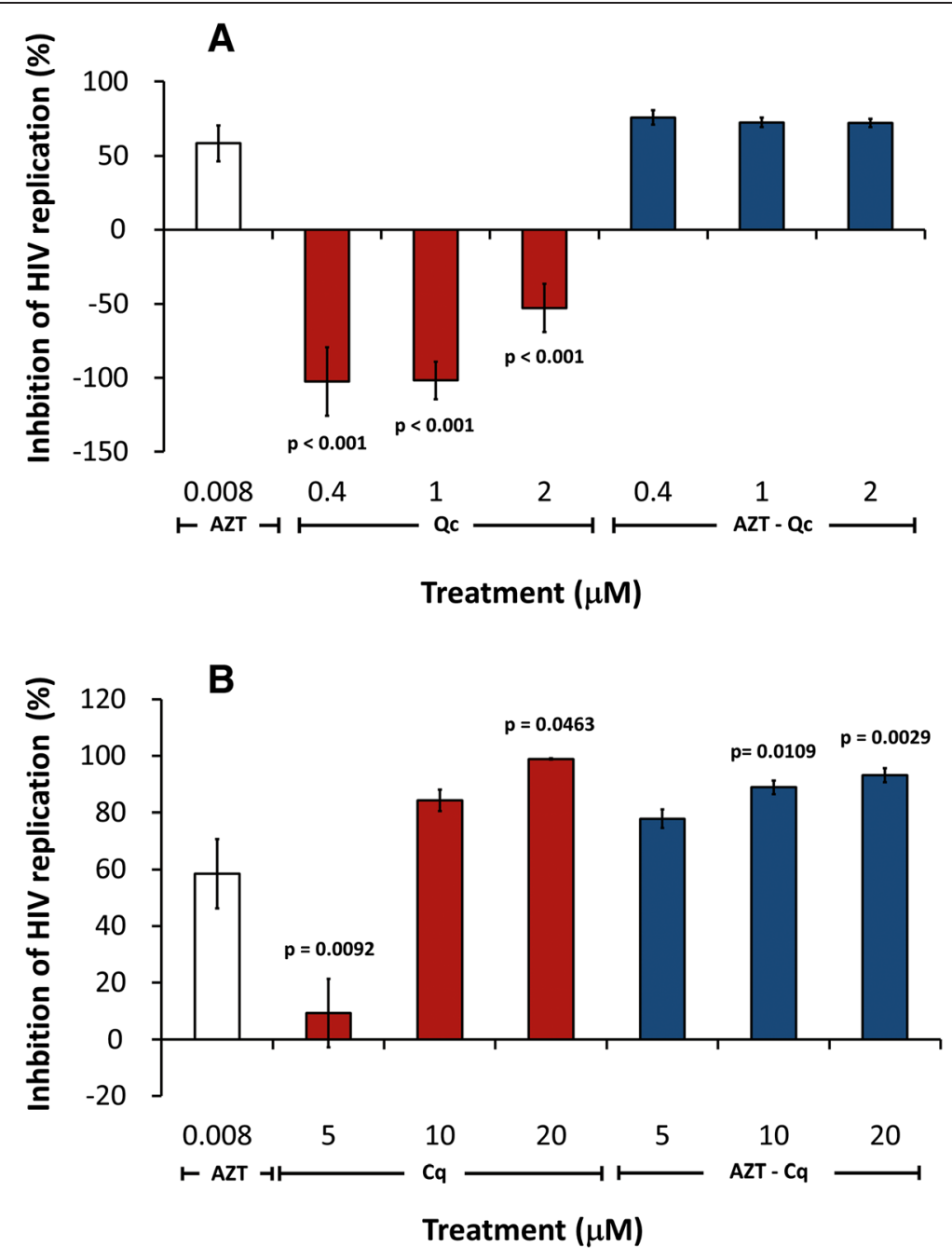

Figure 1 In vitro inhibition of HIV replication by different drug treatments: Quinacrine (A) and Chloroquine (B). HIV p24 antigen (ng/ml) was measured in supernatants of cultures of peripheral blood mononuclear cells, infected with the HIV $\mathrm{SF}_{\mathrm{S} 3} \mathrm{Strain}_{\mathrm{in}}$. Cells were treated during 4 days with 3'-azido-3'-deoxythymidine (AZT) (control), Quinacrine (Qc), Chloroquine (Cq) or the mixtures Qc-AZT or Cq-AZT. Each bar represents the mean $+/-$ standard error of three independent assays by triplicate $(n=9)$. One-way ANOVA, followed by Tukey's post-hoc test, was used to compare: A, Control (AZT) and Qc or AZT- QC; and B, Control (AZT) and Cq or AZT-Cq. Statistical significant p-values are shown in the figure.

of AZT, with the level of inhibition of viral replication produced by Qc plus AZT being similar to that provided by AZT alone (Figure 1A). In contrast, administration of $\mathrm{Cq}$ alone at low dose $(5 \mu \mathrm{M})$ yielded modest, but significant inhibition of viral replication of $10 \%$, while higher dose of $\mathrm{Cq}(20 \mu \mathrm{M})$ inhibited HIV replication around $80 \%$ (Figure $1 \mathrm{~B})(\mathrm{p}=0.0463)$. Inhibition of replication by AZT-Cq combination was higher to that obtained with AZT alone $(\mathrm{p}=0.0035)$, but was similar to that obtained with $\mathrm{Cq}$ alone $(10 \mu \mathrm{M})$ (Figure $1 \mathrm{~B})$.

\section{Discussion}

The aim of the current study, was to evaluate if Qc and $\mathrm{Cq}$ could improve the in vitro effect of the antiretroviral
AZT agent. Qc and Cq were evaluated at different concentrations, administered alone or combined with AZT.

AZT is one of the drugs used in the ART in developing countries of low incomes, where many people do not have access to the expensive new antiretroviral agents [22]. Cq, a widely used drug for the treatment of malaria, has shown antiviral effects [10], lysosomotropic activity [7] and a preferential affinity for lymphoid tissues $[8,9]$, useful properties against HIV. In turn, the anti-HIV effect of Qc, other DNA-intercalating agent [6], has not been evaluated.

Results showed that the treatment of HIV-infected PBMCs with Qc alone, increased HIV replication. This result had not been reported before, but some studies 
have shown a similar effect with cocaine, explained by a possible regulation of the HIV entry in the cells and anti-HIV microRNAs [23,24]. When the combination QcAZT was evaluated, the HIV inhibition was similar to that obtained with AZT alone, which could be explained by the anti-HIV effect of AZT.

Previous reports have shown that Cq inhibits viral replication [25]. In the present study, the same effect was observed at high doses $(10-20 \mu \mathrm{M})$. When these doses were combined with AZT, the inhibition was similar than that obtained with Cq alone, and higher than AZT. This result suggests that the HIV inhibition is related to the intrinsic effect of Cq. The inhibition of HIV replication with a low dose of Cq-AZT (5 and $0.008 \mu \mathrm{M}$, respectively) was not significantly different from that observed by administration of AZT alone. Considering that both effects are independent, the combination AZT-Cq does not improve the anti-HIV effect.

\section{Conclusion}

Given our results, the use of Qc as antimalarial agent in untreated HIV patients should be carefully observed, due to the possible increase of HIV viral load. We can conclude that, neither Cq or Qc improve the efficacy of AZT.

\section{Abbreviations}

ART: Antiretroviral therapy; AZT: 3'-azido-3'-deoxythymidine; Cq: Chloroquine; ELISA: Enzyme-Linked Immunosorbent Assay; HIV: Human Immunodeficiency Virus; ID $_{50}$ : Inhibitory Dose 50\%; NS: Not significant; PBMCs: Peripheral blood mononuclear cells; PBS: Phosphate buffered saline; Qc: Quinacrine; $\mathrm{TCID}_{50}$ : Tissue culture infectious dose $50 \%$.

\section{Competing interests}

The author declares that they have no competing interests.

\author{
Authors' contributions \\ Conceived and designed the experiments: JS, LAC, KJT. Performed the \\ experiments: KJT, LAC. Analyzed the data: KJT, LAC, HJC. Contributed \\ reagents/materials: GRT, LAC. Wrote the paper: KJT, LAC, HJC. Reviewed the \\ paper: KJT, LAC, HJC, GRT, JS. All authors read and approved the final \\ manuscript.
}

\section{Acknowledgements}

The Commission on Gender Equality and the LX-LXI legislatures, and the Commission for Gender Equality of the LXII Legislature of the Chamber of Deputies of Mexico. This work was partially supported by grant 52652-M from the National Council of Science and Technology of México (CONACYT).

\footnotetext{
Author details

'Laboratorio de Neuroimmunoendocrinología, Instituto Nacional de Neurología y Neurocirugía Manuel Velasco Suárez, Av. Insurgentes Sur 3877, 14269 México D F, México. ${ }^{2}$ Centro de Investigación en Enfermedades Infecciosas, Instituto Nacional de Enfermedades Respiratorias Ismael Cosío Villegas, Calzada de Tlalpan 4502, Col. Sección XVI, 14080 México D F, México. ${ }^{3}$ Laboratorio de Neuroinmunología y. ${ }^{4}$ Laboratorio de Neuropsicofarmacología, Av. Insurgentes Sur 3877, Col. La Fama-Tlalpan, 14269 México D F, México. ${ }^{5}$ Departamento de Farmacia, Facultad de Química, Universidad Nacional Autónoma de México, Circuito Interior, Ciudad Universitaria, Col. Copilco, 04510 México D F, México.
}

Received: 15 October 2014 Accepted: 11 February 2015

Published online: 19 March 2015

\section{References}

1. Conway B. The role of adherence to antiretroviral therapy in the management of HIV infection. J Acquir Immune Defic Syndr. 2007;45 Suppl 1:S14-8.

2. Tang MW, Shafer RW. HIV-1 antiretroviral resistance: scientific principles and clinical applications. Drugs. 2012;72:e1-25.

3. Rynes RI. Antimalarial drugs in the treatment of rheumatological diseases. $\mathrm{Br}$ J Rheumatol. 1997;36:799-805.

4. Boelaert JR, Yaro S, Augustijns P, Meda N, Schneider YJ, Schols D, et al. Chloroquine accumulates in breast-milk cells: potential impact in the prophylaxis of postnatal mother-to-child transmission of HIV-1. AIDS (London, England). 2001;15:2205-7.

5. Neely M, Kalyesubula I, Bagenda D, Myers C, Olness K. Effect of chloroquine on human immunodeficiency virus (HIV) vertical transmission. Afr Health Sci. 2003:3:61-7.

6. Rivas L, Murza A, Sánchez-Cortés S, García-Ramos JV. Interaction of antimalarial drug quinacrine with nucleic acids of variable sequence studied by spectroscopic methods. J Biomol Struct Dyn. 2000;18:371-83.

7. Kunze $H$, Hesse B, Bohn E. Effects of antimalarial drugs on several rat-liver lysosomal enzymes involved in phosphatidylethanolamine catabolism. Biochim Biophys Acta. 1982;713:112-7.

8. Aguirre-Cruz L, Torres KJ, Jung-Cook H, Fortuny C, Sánchez E, Soda-Mehry A, et al. Short communication: preferential concentration of hydroxychloroquine in adenoid tissue of HIV-infected subjects. AIDS Res Hum Retroviruses. 2010;26:339-42.

9. González-Hernández I, Aguirre-Cruz L, Sotelo J, López-Arellano R, Morales-Hipólito A, Jung-Cook H. Distribution of hydroxychloroquine in lymphoid tissue in a rabbit model for HIV infection. Antimicrob Agents Chemother. 2014;58:584-6.

10. Savarino A. Use of chloroquine in viral diseases. Lancet Infect Dis. 2011;11:653-4

11. Savarino A, Gennero L, Sperber K, Boelaert JR. The anti-HIV-1 activity of chloroquine. J Clin Virol. 2001;20:131-5.

12. Piconi S, Parisotto S, Rizzardini G, Passerini S, Terzi R, Argenteri B, et al. Hydroxychloroquine drastically reduces immune activation in HIV-infected, antiretroviral therapy-treated immunologic nonresponders. Blood. 2011;118:3263-72.

13. Martinson JA, Montoya CJ, Usuga X, Ronquillo R, Landay AL, Desai SN. Chloroquine modulates HIV-1-induced plasmacytoid dendritic cell alpha interferon: implication for T-cell activation. Antimicrob Agents Chemother. 2010;54:871-81.

14. Gorbachev AV, Gasparian AV, Gurova KV, Gudkov AV, Fairchild RL. Quinacrine inhibits the epidermal dendritic cell migration initiating $T$ cell-mediated skin inflammation. Eur J Immunol. 2007;37:2257-67.

15. Goldman FD, Gilman AL, Hollenback C, Kato RM, Premack BA, Rawlings DJ. Hydroxychloroquine inhibits calcium signals in T cells: a new mechanism to explain its immunomodulatory properties. Blood. 2000;95:3460-6.

16. Cohen SN, Yielding KL. Inhibition of DNA and RNA polymerase reactions by chloroquine. Proc Natl Acad Sci U S A. 1965;54:521-7.

17. Thielmann HW, Popanda O, Edler L. The effects of inhibitors of topoisomerase II and quinacrine on ultraviolet-light-induced DNA incision in normal and xeroderma pigmentosum fibroblasts. J Cancer Res Clin Oncol. 1991;117:19-26.

18. Choi J-H, Yoon JS, Won Y-W, Park B-B, Lee YY. Chloroquine enhances the chemotherapeutic activity of 5 -fluorouracil in a colon cancer cell line via cell cycle alteration. APMIS. 2012;120:597-604.

19. Torres KJ, Gutiérrez F, Espinosa E, Mackewicz C, Regalado J, Reyes-Terán G. CD8+ cell noncytotoxic anti-HIV response: restoration by HAART in the late stage of infection. AIDS Res Hum Retroviruses. 2006;22:144-52.

20. Mackewicz CE, Barker E, Greco G, Reyes-Teran G, Levy JA. Do betachemokines have clinical relevance in HIV infection? J Clin Invest. 1997;100:921-30.

21. McDougal JS, Cort SP, Kennedy MS, Cabridilla CD, Feorino PM, Francis DP, et al. Immunoassay for the detection and quantitation of infectious human retrovirus, lymphadenopathy-associated virus (LAV). J Immunol Methods. 1985;76:171-83.

22. Renaud-Théry F, Avila-Figueroa C, Stover J, Thierry S, Vitoria M, Habiyambere $\checkmark$, et al. Utilization patterns and projected demand of antiretroviral drugs in low- and middle-income countries. AIDS Res Treat. 2011;2011:749041.

23. Mantri CK, Pandhare Dash J, Mantri JV, Dash CCV. Cocaine enhances HIV-1 replication in CD4+ T cells by down-regulating MiR-125b. PLoS One. 2012;7:e51387. 
24. Napuri J, Pilakka-Kanthikeel S, Raymond A, Agudelo M, Yndart-Arias A, Saxena SK, et al. Cocaine enhances HIV-1 infectivity in monocyte derived dendritic cells by suppressing microRNA-155. PLoS One. 2013;8:e83682.

25. Savarino A, Gennero L, Chen HC, Serrano D, Malavasi F, Boelaert JR, et al. Anti-HIV effects of chloroquine: mechanisms of inhibition and spectrum of activity. AIDS (London, England). 2001;15:2221-9.

Submit your next manuscript to BioMed Central and take full advantage of:

- Convenient online submission

- Thorough peer review

- No space constraints or color figure charges

- Immediate publication on acceptance

- Inclusion in PubMed, CAS, Scopus and Google Scholar

- Research which is freely available for redistribution 